\title{
Cross-level interactions in Latin: Vowel shortening, vowel deletion and vowel gliding*
}

\author{
Haike Jacobs \\ Radboud University \\ h.jacobs@let.run.nl
}

Received: April 1, 2019

Accepted: July 4, 2019

\begin{abstract}
Serial and parallel OT differ in the way they account for phonological generalizations referring to more than one level of the prosodic hierarchy. Vowel shortening in Latin is analyzed by McCarthy, Pater \& Pruitt (2016) as a case in point. Vowel shortening takes place to optimize foot structure. In parallel OT, footing and shortening can be evaluated in parallel, but in serial OT footing and shortening necessarily take place in a serial derivation. In this paper, both the serial and the parallel analysis of Latin vowel shortening are critically discussed. After that, two other potential cases of cross-level interactions in Latin are addressed: vowel deletion and vowel gliding. For each of these cases, it is argued that a serial analysis has to be preferred over a parallel one.
\end{abstract}

Keywords: Serial Optimality theory; Parallel Optimality theory; Latin vowel shortening, vowel deletion and vowel gliding; Cross-level interactions; Uneven trochee

Resum. Interaccions entre nivells en llatí: abreujament vocàlic, elisió vocàlica i formació de diftongs

La versió paral·lela i la serial de la teoria de l'optimitat (TO) difereixen entre sí en la manera com expliquen les generalitzacions fonològiques que es refereixen a més d'un nivell de la jerarquia prosòdica. L'abreujament vocàlic en llatí ha estat analitzat per McCarthy, Pater \& Pruitt (2016) com un exemple d'això. L'escurçament es produeix per tal d'optimitzar l'estructura del peu. En la primera versió la construcció dels peus i l'escurçament poden avaluar-se en paral·lel, però en la segona la construcció dels peus i l'abreujament s'han de dur a terme necessàriament en una derivació serial. En aquest article es discuteixen críticament ambdues anàlisis. Després del l'escurçament vocàlic, s'aborden altres dos casos d'interacció entre nivells en llatí: l'elisió vocàlica i la diftongació de vocals. Per a cadascun d'aquests casos, s'argumenta que és preferible una anàlisi serial a una de paral·lela.

Paraules clau: teoria de la optimitat serial; teoria de la optimitat en paral·lel; abreujament, elisió i diftongació de les vocals del llatí; interaccions entre nivells; troqueu asimètric

* I would like to thank two anonymous reviewers for their useful and helpful critical comments and remarks. All remaining errors are my own responsibility. 


\section{Table of Contents}

$\begin{aligned} \text { 0. Introduction } & \text { 3. Vowel gliding and cross-level } \\ \text { 1. Vowel Shortening and cross-level } & \text { interactions } \\ \text { interactions in Harmonic Serialism } & \text { 4. Summary } \\ \text { versus Parallel OT } & \text { References } \\ \text { 2. Vowel deletion } & \\ \text { and cross-level interactions } & \end{aligned}$

\section{Introduction}

McCarthy, Pater \& Pruitt (2016) have drawn attention to a specific difference between parallel OT (Prince \& Smolensky 2004) and serial versions of OT, like Harmonic Serialism (McCarthy 2016). Within Harmonic Serialism, an input form is subject to the constraint grammar of a language and may undergo one single modification, but only if that modification makes the form more harmonic, that is, no longer violating a markedness constraint that is ranked higher than the specific faithfulness constraint that is going to be violated by that single modification. The altered input is then subject again to the same constraint grammar and the process repeats itself until no more harmonic improvement is possible. An input form thus goes step-wise though the constraint grammar to end up as the optimal surface form. In Parallel OT, there is no limitation in terms of the modifications that are allowed. This means that phonological generalizations that refer to more than one level of the prosodic hierarchy cannot be evaluated in parallel, but have to be treated differently in Harmonic Serialism. A case in point is foot-based vowel shortening. If a long vowel is shortened, because it makes a better foot, then in Parallel OT, footing and shortening can be evaluated in parallel, but not in Harmonic Serialism.

This paper is structured as follows. In section 1, the Serial OT analysis of vowel shortening proposed by McCarthy, Pater \& Pruitt (2016) is compared to the Parallel OT analysis of Prince \& Smolensky (2004). We will focus on the different empirical predictions of the two analyses and point out a shared problem: analyzing short pre-final vowels as secondarily stressed in some word types, which as we will show in section 2 is problematic for vowel deletion. Section 2.1 motivates the use of an uneven trochee and of a foot-based vowel deletion constraint. After that, we will show in section 2.2, why a serial analysis is preferred over a parallel one. In section 2.3 we will address the cross-level interaction in Latin vowel deletion. Finally, section 3 discusses the cross-level interaction in vowel gliding and shows why a serial analysis has to be preferred over a parallel one for vowel gliding.

\section{Vowel Shortening and cross-level interactions in Harmonic Serialism versus Parallel OT}

Cretic shortening in Pre-classical Latin is taken as an example by McCarthy, Pater \& Pruitt (2016) of what they call a cross-level interaction, that is, a generalization that refers to more than one level of the prosodic hierarchy. By Cretic shortening, 
the final vowel of a HLH word is shortened, as in words like /de:sino:/ desino 'I cease' or /neskio:/ nescio 'I don't know' that surface as ('de:)(,si.no) and ('nes) (,ki.o) in Pre-classical Latin. Following Mester (1994) and Prince \& Smolensky (2004), the rationale for vowel shortening is assumed to be the fact that it allows for a better or more complete footing: instead of analyzing the word as $\left({ }^{\prime} \mathrm{H}\right) \mathrm{L}\left({ }_{1} \mathrm{H}\right)$ it is analyzed as ('H)(, LH-), where H- stands for a heavy syllable that has been made light. A footing $\left({ }^{\prime} \mathrm{H}\right)\left({ }_{1} \mathrm{LH}-\right)$ is thus equivalent to $\left({ }^{\prime} \mathrm{H}\right)\left({ }_{1} \mathrm{LL}\right)$. In Prince \& Smolensky (2004), following Mester (1994), shortening and footing take place in parallel, that is, the two most relevant output candidates $\left({ }^{\prime} \mathrm{H}\right) \mathrm{L}\left({ }_{1} \mathrm{H}\right)$ and $\left({ }^{\prime} \mathrm{H}\right)\left({ }_{1} \mathrm{LH}-\right)$ are evaluated in parallel in the selection of the optimal output form. The relative ranking of two constraints, one asking for syllables to be parsed in a foot (PARSE- $\sigma$ ) and the other asking that moras not be deleted (MAX- $\mu)$, determines which of the two output forms is optimal: ('H)( $\mathrm{LH}-)$, with one mora deleted, in Pre-classical Latin and $\left({ }^{\prime} \mathrm{H}\right)$ $\mathrm{L}(\mathrm{H})$, with no mora deleted, but with one unparsed syllable, in Classical Latin. This is illustrated in (1) and (2), in which we have indicated a shortened $\mathrm{H}$ syllable directly as $\mathrm{L}$ instead of $\mathrm{H}$ - in the output forms.

(1) Cretic shortening in Pre-classical Latin

\begin{tabular}{|c|l|l|}
\hline$/$ der.si.no:/ & PARSE- $\sigma$ & MAX- $\mu$ \\
\hline$\left({ }^{\prime} H\right) L(, H) \quad[($ 'de: $) \operatorname{si}(, n o:)$ & $* !$ & \\
\hline$\left({ }^{\prime} H\right)\left({ }_{1} L L\right) \quad\left[(\right.$ 'de: $)\left({ }_{1}\right.$ si.no $\left.)\right]$ & & $*$ \\
\hline
\end{tabular}

(2) Vowel length respected in Classical Latin

\begin{tabular}{|c|c|c|}
\hline /der.si.no:/ & MAX- $\mu$ & PARSE- $\sigma$ \\
\hline$\left({ }^{\prime} \mathrm{H}\right) \mathrm{L}(, \mathrm{H}) \quad\left[\left({ }^{\prime} \mathrm{de}:\right) \operatorname{si}(, \mathrm{no:})\right.$ & & $*$ \\
\hline$\left({ }^{\prime} \mathrm{H}\right)\left({ }_{1} \mathrm{LL}\right) \quad\left[\left({ }^{\prime} \mathrm{de}:\right)\left({ }_{1}\right.\right.$ si.no $\left.)\right]$ & $* !$ & \\
\hline
\end{tabular}

In Harmonic Serialism, this analysis is not possible. Vowel shortening and footing constitute both a single modification, which implies that necessarily one has to precede the other. If the vowel is shortened for foot harmony reasons, this means that the foot, which is going to be improved by the shortening, has to be there before the actual shortening takes place. This is the way Cretic shortening is analyzed in McCarthy, Pater \& Pruitt (2016). A trochaic ( $\mathrm{LH})$ foot, although it never appears in Latin surface forms, is allowed as an intermediate foot in the harmonically serial evaluation. This is an example of what is called a 'violation of the surface-true'. The intermediate $(\mathrm{LH})$ foot violates the constraint WSP (a heavy syllable may not be located in the weak part of a foot) which is surface-unviolated in Latin (cf. McCarthy, Pater \& Pruitt (2016) for a more detailed discussion). ${ }^{1}$ The

1. The choice between the two possible Classical Latin output forms ('H)L(,H) or ('H)(,LH) depends on the ranking of the constraint WSP (a heavy syllable may not may not be located in the weak part 
intermediate ( $\mathrm{LH}$ ) foot is then turned into a ( $\mathrm{LH}-$ ) foot (or equivalently ( $\mathrm{LL})$ ), that is, with a shortened vowel, at the next round of evaluation. Let us briefly illustrate their analysis. For the derivation of surface ('de:)(si.no), the following steps are assumed: /de:sino:/ $\rightarrow$ de:.si.no: $\rightarrow$ ('de:)si.no: $\rightarrow$ ('de:)(si.no: $\rightarrow$ ('de:)(, si.no). The relevant steps are illustrated, after syllabification at step 1, in tableaux (3) to (5) below.

The NonFinality constraint is split into two constraints NonFIn (MAIN- $\sigma$ ), the main stressed syllable may not be final, and NONFIN (MAIN-FT), the foot with main stress may not be final. The constraint RHHRM, rhythmic harmony, rules out uneven trochees, that is ('HL) feet and the constraint ALIGN-R (MAIN- $\sigma$ ) requires the main stressed syllable to be the final syllable of the word (the number of syllables indicates the distance away from the word edge).

(3) Step 2: de:.si.no: going to ('de:)si.no:. HLH becomes ('H)LH

\begin{tabular}{|c|l|l|l|l|l|l|l|}
\hline$/$ de:.si.no:/ & $\begin{array}{l}\text { Non-FIN } \\
\text { MAIN- } \sigma\end{array}$ & RHHRM & $\begin{array}{l}\text { Non-FIN } \\
\text { MAIN-FT }\end{array}$ & $\begin{array}{l}\text { ALIGN-R } \\
\text { MAIN- } \sigma\end{array}$ & PARSE- $\sigma$ & WSP & MAX- $\mu$ \\
\hline$\left({ }^{\prime} \mathrm{H}\right) \mathrm{LH}$ & & & & $\sigma \sigma$ & $* *$ & & \\
\hline$\left({ }^{\prime} \mathrm{HL}\right) \mathrm{H}$ & & $* !$ & & $\sigma \sigma$ & $*$ & & \\
\hline $\mathrm{H}\left({ }^{\prime} \mathrm{LH}\right)$ & & & $* !$ & $\sigma$ & $*$ & $*$ & \\
\hline $\mathrm{HL}\left({ }^{\prime} \mathrm{H}\right)$ & $* !$ & & $*$ & & $* *$ & & \\
\hline
\end{tabular}

(4) Step 3: ('de:)si.no: going to ('de:)(, si.no:). ('H)LH becomes ('H)(,LH)

\begin{tabular}{|c|l|l|l|l|l|l|l|}
\hline ('de:)si.no: & $\begin{array}{l}\text { Non-Fin } \\
\text { MAIN- } \sigma\end{array}$ & RHHRM & $\begin{array}{l}\text { NON-Fin } \\
\text { MAIN-FT }\end{array}$ & $\begin{array}{l}\text { Align-R } \\
\text { MAIN- } \sigma\end{array}$ & PARSE- $\sigma$ & WSP & MAX- $\mu$ \\
\hline$(' \mathrm{H})(\mathrm{LH})$ & & & & $\sigma \sigma$ & & $*$ & \\
\hline$(' \mathrm{H}) \mathrm{LH}$ & & & & $\sigma \sigma$ & $* ! *$ & & \\
\hline$(' \mathrm{H}) \mathrm{L}\left({ }_{1} \mathrm{H}\right)$ & & & & $\sigma \sigma$ & $* !$ & & \\
\hline
\end{tabular}

of a foot). If this constraint is located below PARSE- $\sigma$ and MAX- $\mu,\left({ }^{\prime} H\right)(\mathrm{LH})$ is the predicted optimal result, if it is ranked above MAX- $\mu$, but below PARSE- $\sigma,\left({ }^{\prime} H\right) L(H)$ is predicted to be optimal. 
(5) Step 4: shortening ('de:)(, si.no:) going to ('de:)(, si.no). ('H)(, LH) becomes $(\mathrm{H})(, \mathrm{LL})$

\begin{tabular}{|c|c|c|c|c|c|c|c|}
\hline$($ 'de: $)($,si.no) & $\begin{array}{l}\text { Non-FIN } \\
\text { MAIN- } \sigma\end{array}$ & RHHRM & $\begin{array}{l}\text { NoN-FIN } \\
\text { MAIN-FT }\end{array}$ & $\begin{array}{l}\text { ALIGN-R } \\
\text { MAIN- } \sigma\end{array}$ & PARSE- $\sigma$ & WSP & МАХ $-\mu$ \\
\hline$\left({ }^{\prime} \mathrm{H}\right)(\mathrm{LH})$ & & & & $\sigma \sigma$ & & $* !$ & \\
\hline$\left({ }^{\prime} H\right)(, L L)$ & & & & $\sigma \sigma$ & & & $*$ \\
\hline$\left({ }^{\prime} \mathrm{H}\right) \mathrm{L} \mathrm{H}$ & & & & $\sigma \sigma$ & $* ! *$ & & \\
\hline$\left({ }^{\prime} \mathrm{H}\right) \mathrm{L}(\mathrm{H})$ & & & & $\sigma \sigma$ & $* !$ & & \\
\hline
\end{tabular}

By ranking PARSE- $\sigma$ above WSP the analysis thus arrives at having a secondary quantity-insensitive foot $\left({ }_{1} \mathrm{LH}\right)$ in the course of the derivation, at step 3 in (4), and then improving on it at step 4 in (5). McCarthy, Pater \& Pruitt remark "Thus, although $(\mathrm{LH})$ trochees are absent from surface forms, they emerge and are later eliminated by shortening in the course of the derivation."

Iambic shortening, so-called because it takes place in words that have an iambic input shape /LH/, like /a.mo:/ amo 'I love' surfacing as ('a.mo) in Pre-classical Latin, is analyzed in a similar way, as illustrated in (6) and (7), where we have added the constraint FT-BIN, a foot must be binary (consisting of two syllables or two moras).

(6) Step 2: a.mo: going to ('a.mo:). LH becomes ('LH)

\begin{tabular}{|c|l|l|l|l|l|l|l|}
\hline /a.mo:/ & $\begin{array}{l}\text { Non-Fin } \\
\text { MAIN- } \sigma\end{array}$ & FtBIN & $\begin{array}{l}\text { Non-Fin } \\
\text { MAIN-FT }\end{array}$ & $\begin{array}{l}\text { ALIGN-R } \\
\text { MAIN- } \sigma\end{array}$ & PARSE- $\sigma$ & WSP & MAX- $\mu$ \\
\hline ('LH) & & & $*$ & $\sigma$ & $*$ & \\
\hline L('H) & $* !$ & & $*$ & & $*$ & & \\
\hline$(' \mathrm{~L}) \mathrm{H}$ & & $* !$ & & $\sigma$ & $*$ & & \\
\hline
\end{tabular}

(7) Step 3: ('a.mo:) going to ('a.mo). ('LH) becomes ('LL)

\begin{tabular}{|c|l|l|l|l|l|l|l|}
\hline ('a.mo:) & $\begin{array}{l}\text { Non-Fin } \\
\text { MAIN- } \sigma\end{array}$ & FTBIN & $\begin{array}{l}\text { Non-Fin } \\
\text { MAIN-FT }\end{array}$ & $\begin{array}{l}\text { ALIGN-R } \\
\text { MAIN- }\end{array}$ & PARSE- $\sigma$ & WSP & MAX- $\mu$ \\
\hline$($ 'LL) & & & $*$ & $\sigma$ & & & $*$ \\
\hline$($ 'LH $)$ & & & $*$ & $\sigma$ & & $* !$ & \\
\hline
\end{tabular}


A number of remarks are in order. While a ( $\mathrm{LH})$ or a ('LH) trochee (with secondary stress as in (4) or with main stress as in (6)), may be allowed in the course of the derivation, a non-final main stressed foot (' $\mathrm{LH}$ ) trochee obviously needs to be avoided, as this would lead to the incorrect prediction of shortening a long vowel with primary stress. This is taken care of by the ALIGN-R (MAIN- $\sigma$ ) constraint that requires the main stressed syllable to be the final syllable of the word, as illustrated for [a.'mi:.kum] amicum 'friend' in (8).

(8) Main stress for amicum: a.mi:.kum going to a('mi:)kum. LHL becomes $\mathrm{L}\left({ }^{\prime} \mathrm{H}\right) \mathrm{L}$

\begin{tabular}{|c|l|l|l|l|l|l|l|}
\hline /a.mi:.kum/ & $\begin{array}{l}\text { Non-FIN } \\
\text { MAIN- } \sigma\end{array}$ & RHHRm & $\begin{array}{l}\text { Non-FIN } \\
\text { MAIN-FT }\end{array}$ & $\begin{array}{l}\text { ALIGN-R } \\
\text { MAIN- } \sigma\end{array}$ & PARSE- $\sigma$ & WSP & MAX- $\mu$ \\
\hline L('H)H & & & & $\sigma$ & $* *$ & & \\
\hline$(' \mathrm{LH}) \mathrm{H}$ & & & & $\sigma \sigma !$ & $*$ & $*$ & \\
\hline $\mathrm{LH}\left({ }^{\prime} \mathrm{H}\right)$ & $* !$ & & $*$ & & $* *$ & & \\
\hline
\end{tabular}

McCarthy, Pater \& Pruitt (2016) mention an interesting difference between their analysis and the original parallel analysis advanced by Prince \& Smolensky (2004). In that analysis, the Pre-classical Latin optimal output form for cretic / $\mathrm{HLH} /$ words, that is $\left({ }^{\prime} \mathrm{H}\right)\left({ }_{1} \mathrm{LL}\right)$, has an interesting competitor in the surface form $(' \mathrm{LL})(\mathrm{H})$, that is, a surface form that fares equally well in terms of completely footing all syllables, but in which it is not the final syllable that is shortened, but the vowel of the main stressed syllable. A potential surface output ('de.si)(,no:) is thus compared to actual optimal ('de:)(, si.no). The selection of ('H)( $\left.{ }_{1} L L\right)$ over ('LL) $\left.{ }_{1} H\right)$ is taken care of by Prince \& Smolensky (2004) by invoking the Peak-Prominence constraint in (9).

\section{(9) Peak-Prominence (Pk-Prom): $\quad$ Peak (x) > Peak (y) if $|x|>|y|$}

According to the Peak Prominence constraint (x) is a better peak than (y) if its intrinsic prominence is greater than that of $(\mathrm{y})$. A heavy syllable is thus a better peak than a light syllable. This is illustrated in tableau (10) where we have left out the two Non-FIn constraints. Both output forms (10a) and (10b) are equally good in terms of the relative ranking of PARSE- $\sigma$ and MAX- $\mu$, but differ in their compliance with the last ranked constraint PK-PROM (cf. Prince \& Smolensky 2004: 76). 
(10) Parallel parsing of HLH

\begin{tabular}{|c|c|c|c|c|c|c|}
\hline $\begin{array}{l}\text { /de:si.no/ } \\
\text { /HLH/ }\end{array}$ & WSP & RHHRM & $\begin{array}{l}\text { A L I G N - R } \\
\text { MAIN- } \sigma\end{array}$ & PARSE- $\sigma$ & MAX- $\mu$ & PK-Prom \\
\hline a. $\left({ }^{\prime} \mathrm{H}\right)(\mathrm{LL})$ & & & $\sigma \sigma$ & & $*$ & $|\mathrm{H}|$ \\
\hline b. $\left({ }^{\prime} \mathrm{LL}\right)\left({ }_{1} \mathrm{H}\right)$ & & & $\sigma \sigma$ & & $*$ & $|\mathrm{~L}| !$ \\
\hline c. $\left({ }^{\prime} \mathrm{H}\right) \mathrm{L}\left({ }_{1} \mathrm{H}\right)$ & & & $\sigma \sigma$ & $* !$ & & $|\mathrm{H}|$ \\
\hline d. $\left({ }^{\prime} \mathrm{H}\right)(\mathrm{L} \mathrm{LH})$ & $* !$ & & $\sigma \sigma$ & & & $|\mathrm{H}|$ \\
\hline e. $\left({ }^{\prime} \mathrm{HL}\right)\left({ }_{1} \mathrm{H}\right)$ & & $* !$ & $\sigma \sigma$ & & & $|\mathrm{H}|$ \\
\hline
\end{tabular}

In their further discussion of the constraint PK-Prom, Prince \& Smolensky (2004: 78-79) suggest that the constraint holds for all peaks or heads, but that the evaluation of the head of the PRWD takes priority over the evaluation of foot heads. So, in order to be precise, both output candidate (10a) and (10b) in fact entail a violation of PK-Prom. Given that (10a) has a PK-PrOM violation of a foot that is not the main stressed foot, whereas in (10b) the main foot violates PK-Prom, (10a) is evaluated as being better than (10b). The displayed evaluations for PK-PROM in (10) should thus be interpreted as referring to the foot that has main stress, that is, the first foot in the output forms. The initial foot in (10b) has a L peak, but a H one in (10a) and the other output forms.

McCarthy, Pater \& Pruitt (2016: 12) remark that in their Harmonic Serialism analysis, the competition between $\left({ }^{\prime} \mathrm{H}\right)\left({ }_{1} \mathrm{LL}\right)$ and $\left({ }^{\prime} \mathrm{LL}\right)\left({ }_{1} \mathrm{H}\right)$, that is between $\left({ }^{\prime} \mathrm{de}:\right)\left({ }_{1} \mathrm{si}\right.$. no) and ('de.si)(,no:), is an issue that simply does not arise, given that

*('de.si)(,no:) is never even a candidate, much less a serious challenger to the intended winner. It is not a candidate because it would require an intermediate step with a ('HL) trochee, ('de.si). Undominated RHHRM ensures that such feet never win even at intermediate derivational steps. The HS analysis therefore has an advantage over the P-OT analysis: it can explain, and need not stipulate, which syllable is affected by cretic shortening.

McCarthy, Pater \& Pruitt (2016) observe a further difference between their serial and the original parallel analysis. Two heavy syllables before the main stressed syllable are predicted to become $\left({ }_{1} \mathrm{HH}\right)$ in the serial analysis, but $\left.{ }_{1} \mathrm{H}\right)\left({ }_{1} \mathrm{H}\right)$ in the parallel analysis. McCarthy, Pater \& Pruitt mention as an example /au.di:.to:.te/ auditote 'hear! (fut.pl.)'. Their serial analysis predicts (,au.di:)('to:)te, whereas the parallel analysis predicts $(\mathrm{au})(\mathrm{di})($ 'to: $)$ te. This difference is due to the fact that in the serial analysis PARSE- $\sigma$ dominates WSP, whereas in the parallel analysis the opposite ranking holds. The parallel analysis is illustrated in (11), the serial one in is given in (12), where we pick up the derivation after main stress assignment and where we have left out lower-ranked MAX- $\mu$. 
(11) Parallel parsing of HHHL /au.dir.to:.te/ as (,au)(dii)('to:)te

\begin{tabular}{|l|l|l|l|l|}
\hline $\begin{array}{l}\text { /au.di:.to:.te/ } \\
\text { /HHHL/ }\end{array}$ & WSP & RHHRM & $\begin{array}{l}\text { Align-R } \\
\text { MAIN- } \sigma\end{array}$ & PARSE- $\sigma$ \\
\hline a. $\left({ }_{1} \mathrm{HH}\right)\left({ }^{\prime} \mathrm{H}\right) \mathrm{L}$ & $* !$ & & $\sigma$ & $*$ \\
\hline b. ${ }^{-}\left({ }_{1} \mathrm{H}\right)\left({ }_{1} \mathrm{H}\right)\left({ }^{\prime} \mathrm{H}\right) \mathrm{L}$ & & & $\sigma$ & $*$ \\
\hline c. $\left({ }_{1} \mathrm{H}\right) \mathrm{H}\left({ }^{\prime} \mathrm{H}\right) \mathrm{L}$ & & & $\sigma$ & $* * !$ \\
\hline d. $\mathrm{HH}\left({ }^{\prime} \mathrm{H}\right) \mathrm{L}$ & & & $\sigma$ & $* * ! *$ \\
\hline
\end{tabular}

(12) Step 3: au.di:('to:)te going to (, au.di:)('to:)te $\mathrm{HH}\left({ }^{\prime} \mathrm{H}\right) \mathrm{L}$ becoming $\left({ }_{1} \mathrm{HH}\right)\left({ }^{\prime} \mathrm{H}\right) \mathrm{L}$

\begin{tabular}{|c|c|c|c|c|c|c|}
\hline /au.dir('to:)te/ & $\begin{array}{l}\text { NoN-FIN } \\
\text { MAIN- } \sigma\end{array}$ & RHHRM & $\begin{array}{l}\text { Non-FIN } \\
\text { MAIN-FT }\end{array}$ & $\begin{array}{l}\text { AliGN-R } \\
\text { MAIN- } \sigma\end{array}$ & Parse- $\sigma$ & WSP \\
\hline$\left({ }_{1} \mathrm{H}\right) \mathrm{H}\left({ }^{\prime} \mathrm{H}\right) \mathrm{L}$ & & & & $\sigma$ & $* * !$ & \\
\hline$\left({ }_{1} \mathrm{HH}\right)\left({ }^{\prime} \mathrm{H}\right) \mathrm{L}$ & & & & $\sigma$ & $*$ & $*$ \\
\hline $\mathrm{H}\left({ }_{1} \mathrm{H}\right)\left({ }^{\prime} \mathrm{H}\right) \mathrm{L}$ & & & & $\sigma$ & $* * !$ & \\
\hline
\end{tabular}

Please observe that the optimal initial foot resulting at step 3 in (12) contains a violation of WSP that cannot be improved upon further. Shortening at a next step, (, au.di:) going to (,au.di) and incurring a violation of lower-ranked MAX- $\mu$, is blocked by the higher-ranked, undominated RHHRM constraint. This means that, rather counter-intuitively, the serial analysis allows a trochaic foot $(\mathrm{HH})$, while disallowing a (HL) one.

This leads to yet another difference between the Parallel and the Serial OT analysis. It is not only in the stressing of two heavy syllables before the main stressed syllable, as observed by McCarthy, Pater and Pruitt, that the two analyses differ, but also in the stressing of a heavy and a light syllable before the main stressed syllable. Prince \& Smolensky (2004: 79) remark: "We expect $\left({ }_{1} \mathrm{H}-\mathrm{L}\right)\left({ }^{\prime} \mathrm{H}\right)$ $(, \mathrm{H})$ from HLHH. This avoids the Foot Form violation (HL) [...] and it achieves complete foot parsing at the expense of MAX- $\mu$." This is illustrated in (13) for a word like /ki:.wi.ta:.tem/ civitatem 'city', where this time, given that the foot with main stress has a $\mathrm{H}$ peak in all three output forms, the displayed evaluations for PK-PROM should be interpreted as referring to the initial foot with secondary stress. 
(13) Parallel parsing of HLHH

\begin{tabular}{|l|l|l|l|l|l|l|}
\hline $\begin{array}{l}\text { /ki.wi.ta:.tem/ } \\
\text { /HLHH/ }\end{array}$ & WSP & RHHrm & $\begin{array}{l}\text { A L I G N - R } \\
\text { MAIN- } \sigma\end{array}$ & PARSE- $\sigma$ & MAX- $\mu$ & PK-PROM \\
\hline a. ${ }_{1}$ LL $)\left({ }^{\prime} \mathrm{H}\right)\left({ }_{1} \mathrm{H}\right)$ & & & $\sigma$ & & $*$ & $|\mathrm{~L}|$ \\
\hline b. $\quad\left({ }_{1} \mathrm{HL}\right)\left({ }^{\prime} \mathrm{H}\right)\left({ }_{1} \mathrm{H}\right)$ & & $* !$ & $\sigma$ & & $|\mathrm{H}|$ \\
\hline c. $\quad\left({ }_{1} \mathrm{H}\right) \mathrm{L}\left({ }^{\prime} \mathrm{H}\right)\left({ }_{1} \mathrm{H}\right)$ & & & $\sigma$ & $* !$ & & $|\mathrm{H}|$ \\
\hline
\end{tabular}

The serial analysis could never produce this result as it would require a (, HL) trochee at an intermediate step in the serial derivation. It is doubtful, however, whether shortening did apply to the initial vowel in such cases in Pre-classical Latin, all we know for sure is that the initial vowel was long in Classical Latin as witnessed by modern Romance reflexes such as French cité, Italian città, Spanish ciudad etc. which all show a long initial vowel, a short one would have merged as [e] with original Latin long [e:].

Furthermore, it should be observed that both analyses predict vowel shortening to take place in a pre-main stress LHL sequence. In the serial analysis, the ALIGN-R (MAIN- $\sigma$ ) constraint, contrary to the main stress environment in (8) above, is not preventing LHL in the pre-main stress sequence from becoming optimally analysed as $\left({ }_{1} \mathrm{LH}\right) \mathrm{L}$ and then further improved by vowel shortening to surface as (,LH-)L. Vowel shortening in Pre-classical Latin was, however, restricted to final vowels and word-internally did affect heavy syllables (closed heavy syllables, but rarely heavy syllables with a long vowel (cf. Drexler 1969: 214; Mester 1994), only if they were immediately followed by main stress (cf. Allen 1973: 181; Lindsay 1894: 201-202). The word-internal de-weighting of closed, heavy syllables is therefore better analysed as clash avoidance and the shortening of final vowels as final vowel shortening (cf. Jacobs 2003 for a more detailed account). Such an analysis does not need to invoke intermediate trochaic feet $(\mathrm{LH})$, but also raises the question what it is that makes the final long vowel in cretic HLH words special. From a Classical Latin poetry perspective the obvious answer seems to be that these words, just as LLLH words, like balineum 'bath', cupiditas 'lust', maritimus 'maritime' or manipulum 'a fistful', simply do not fit in a dactylic hexameter. In Classical Latin poetry, these LLLH words simply do not occur just as words of a cretic type, HLH, were generally avoided. The only way in which LLLH words could occur in Classical poetry is in syncopated form. This is shown clearly by comparing LLLH words like manipulum to LHLH words like periculum 'danger', Both have main stress on the antepenultimate syllable, but differ in that [i] is long in periculum, but short in manipulum. A word like periculum frequently occurs in Vergil and Ovid both in syncopated and in unsyncopated (always as LHLL pericula) form, but manipulum only occurs in syncopated form and never in its full form. Let us briefly summarize in (14) the differences between the serial and the parallel analyses of vowel shortening in Pre-classical Latin. 
(14) Summarizing the differences between the parallel and serial vowel shortening analyses

$\begin{array}{lll}\begin{array}{l}\text { Different predictions } \\ \text { HHHL /au.di:.to:.te/ }\end{array} & \text { Parallel } & \text { Serial } \\ & \left({ }_{1} \text { au }\right)\left({ }_{1} \text { di: }\right)\left({ }^{\prime} \text { to: }\right) \text { te } & (, \text { au.di: })(\text { 'to: }) \text { te } \\ & \left({ }_{1} \mathrm{H}\right)\left({ }_{1} \mathrm{H}\right)\left({ }^{\prime} \mathrm{H}\right) \mathrm{L} & \left({ }_{1} \mathrm{HH}\right)\left({ }^{\prime} \mathrm{H}\right) \mathrm{L} \\ \text { HLHH /ki.wi.ta:.tem/ } & \left({ }_{1} \text { ki.wi }\right)\left({ }^{\prime} \text { ta: }\right)\left({ }_{1} \text { tem }\right) & \left({ }_{1} \mathrm{ki}\right) w i\left({ }^{\prime} \text { ta: }\right)(\text { tem }) \\ & \left({ }_{1} \mathrm{LL}\right)\left({ }^{\prime} \mathrm{H}\right)\left({ }_{1} \mathrm{H}\right) & \left({ }_{1} \mathrm{H}\right) \mathrm{L}\left({ }^{\prime} \mathrm{H}\right)\left({ }_{1} \mathrm{H}\right)\end{array}$

The most problematic aspect of both the serial and the parallel analysis of Latin vowel shortening is that a penultimate unstressed vowel is not uniformly analysed as being unstressed, but is sometimes analysed as having secondary stress, that is, as $\left({ }^{\prime} \mathrm{H}\right)(\mathrm{LL})$ in HLL words or in HLH words, analysed as ('H)(, $\left.\mathrm{LH}-\right)$ in Pre-classical and as $\left({ }^{\prime} \mathrm{H}\right) \mathrm{L}\left({ }_{1} \mathrm{H}\right)$ or $\left({ }^{\prime} \mathrm{H}\right)\left({ }_{1} \mathrm{LH}\right)$ (cf. footnote 1 above) in Classical Latin. This is due to the fact that the constraint Non-FIn (MAIN-FT) is specified for the foot with main stress. In Jacobs (2004) it was proposed that by replacing the constraint NON-FIN (MAIN-FT) by the constraint NON-FIN (FT) (a foot may not be final) a uniform analysis of unstressed prefinal vowels as effectively unstressed obtains. The replacement was shown to be independently required for typology in Jacobs (1999) on the basis of the observation that leftward footing never leads to pre-antepenultimate stress, but that only rightward footing ever does so. McCarthy (2003) argues for a similar replacement based on arguments against foot extrametricality. A uniform analysis of unstressed prefinal vowels as unstressed is motivated by Latin vowel deletion or syncope to which we will turn in the next section where we will discuss a cross-level interaction that seems to hold for Latin vowel deletion.

\section{Vowel deletion and cross-level interactions}

In this section we turn to another potential cross-level interaction in Latin vowel deletion. We will first, in section 2.1, motivate the use of the uneven trochee and a foot-based vowel deletion constraint. After that, we will show in section 2.2 why a serial analysis needs to be preferred over a parallel one. Section 2.3 discusses the cross-level constraint interaction involved in Latin vowel deletion.

\subsection{Vowel deletion, even and uneven trochees and foot-based deletion constraints}

In Latin, vowel deletion affected the unstressed post-tonic vowel in all the prosodic word types illustrated in (15).

(15) Vowel deletion in Latin
a. 'HLL type lāmĭnă
'plate' becoming ['lamna]
b. 'LLH
type sŏlǐdus
'solid'
becoming ['soldus]
c. 'HLH
type ārĭdus 'dry'
becoming ['ardus] 
As mentioned above, by replacing the constraint Non-FIN (MAIN-FT) (a foot with main stress may not be final) by a constraint NoN-FIN (FT) (a foot may not be final), the unstressed penultimate vowels are analysed as unstressed, and, if the constraint RHHRM is ranked below PARSE- $\sigma$, they all occupy the weak part of a foot in Jacobs (2004). That Parallel OT analysis is illustrated in (16).

(16) Latin stress with Non-Fin (FT) and RHHRm dominated by PARSE- $\sigma$

\begin{tabular}{|c|c|c|c|c|c|c|}
\hline (16a) /HLL/ & $\begin{array}{l}\text { Non-FIN } \\
(\mathrm{FT})\end{array}$ & FT-BIN & $\begin{array}{l}\text { ALIGN-R } \\
\text { MAIN- } \sigma\end{array}$ & WSP & PARSE- $\sigma$ & RHHRM \\
\hline \multicolumn{7}{|l|}{ lāmīnă } \\
\hline$\left({ }^{\prime} \mathrm{H}\right)(\mathrm{LL})$ & $* !$ & & $\sigma \sigma$ & & & \\
\hline$\left({ }_{1} \mathrm{H}\right)\left({ }^{\prime} \mathrm{LL}\right)$ & $* !$ & & $\sigma$ & & & \\
\hline$\left({ }^{\prime} \mathrm{H}\right) \mathrm{LL}$ & & & $\sigma \sigma$ & & $* * !$ & \\
\hline$\left({ }^{\prime} \mathrm{HL}\right) \mathrm{L}$ & & & $\sigma \sigma$ & & $*$ & $*$ \\
\hline
\end{tabular}

\begin{tabular}{|c|c|c|c|c|c|c|}
\hline$(16 b) / L L H /$ & $\begin{array}{l}\text { Non-FIN } \\
(\mathrm{FT})\end{array}$ & FT-BIN & $\begin{array}{l}\text { ALIGN-R } \\
\text { MAIN- } \sigma\end{array}$ & WSP & PARSE $-\sigma$ & RHHRM \\
\hline \multicolumn{7}{|l|}{ sŏlǐdus } \\
\hline$\left({ }^{\prime} \mathrm{LL}\right)\left({ }_{1} \mathrm{H}\right)$ & $* !$ & & & & & \\
\hline$\left({ }^{\prime} \mathrm{L}\right) \mathrm{LH}$ & & $* !$ & $\sigma \sigma$ & & $* *$ & \\
\hline$(1 \mathrm{LL}) \mathrm{H}$ & & & $\sigma \sigma$ & & $*$ & \\
\hline L('LH) & $* !$ & & $\sigma$ & $*$ & $*$ & \\
\hline
\end{tabular}

\begin{tabular}{|l|l|l|l|l|l|l|}
\hline$(16 \mathrm{c}) / \mathrm{HLH} /$ & $\begin{array}{l}\text { NonFIN } \\
(\mathrm{FT})\end{array}$ & FT-BIN & $\begin{array}{l}\text { Align-R } \\
\text { MAIN- } \sigma\end{array}$ & WSP & PARSE $-\sigma$ & RHHRM \\
\hline ārĭdus & & & & & & \\
\hline$\left({ }^{\prime} \mathrm{H}\right) \mathrm{L}\left({ }_{1} \mathrm{H}\right)$ & $* !$ & & $\sigma \sigma$ & & $*$ & \\
\hline$\left({ }_{1} \mathrm{H}\right) \mathrm{L}\left({ }^{\prime} \mathrm{H}\right)$ & $* !$ & & & & $*$ & \\
\hline $\mathrm{H}\left({ }^{\prime} \mathrm{L}\right) \mathrm{H}$ & & $* !$ & $\sigma$ & & $* *$ & \\
\hline$\left({ }^{\prime} \mathrm{H}\right) \mathrm{LH}$ & & & $\sigma \sigma$ & & $* * !$ & \\
\hline$\left({ }^{\prime} \mathrm{H}\right)\left({ }_{1} \mathrm{LH}\right)$ & $* !$ & & $\sigma \sigma$ & $*$ & & $*$ \\
\hline$\sigma\left({ }^{\prime} \mathrm{HL}\right) \mathrm{H}$ & & & $\sigma \sigma$ & & $*$ & $*$ \\
\hline
\end{tabular}

The relative ranking of the constraints RHHRM and PARSE- $\sigma$ thus produces moraic trochees (if RHHRM dominates PARSE- $\sigma$ ) or uneven trochees (if PARSE- $\sigma$ dominates RHHRM). 
The assumption of a canonical even trochee, that is $(\mathrm{H})$ or $(\mathrm{LL})$ ones, and the claimed universal absence of uneven or (HL) trochees (The Iambic-Trochaic Law Hayes (1995)) was originally, among other things, based upon trochaic shortening in languages such as Fijian, where a HL sequence by shortening becomes an even trochee, as in ('mbu:) 'grandmother' with a heavy syllable turning into a light one in /'mbu: ygu/ $\rightarrow$ ('mbu-ygu), /HL/ $\rightarrow$ (LL), 'my grandmother' (cf. Hayes 1995: 145). Under a Serial OT analysis of trochaic shortening in Fijian or of tri-syllabic laxing in English, if the shortening is analysed as taking place for foot harmony reasons, an uneven trochee has to be allowed at an intermediate step of the derivation and hence cannot be excluded as a possible foot type. ${ }^{2}$

In the history of Latin, syncope never affected stressed vowels and all unstressed penultimate vowels in the word types in (15) were subject to deletion, which is the main reason why they should uniformly be analysed as unstressed. However, it is not immediately clear whether the constraint responsible for vowel deletion should really make reference to the foot. Either a constraint *WEAK-V IN FT (cf. Jacobs 2004), no weak vowel in a foot, or a constraint *WEAK-V, no vowel in an open, unstressed non-final syllable (cf. McCarthy 2008), if ranked above a constraint militating against vowel deletion, MAX-V(OWEL), successfully accounts for Latin vowel deletion, and will target the same vowel in the word types in (15), whether analysed with even or with uneven trochees, as illustrated in (17).

(17) Even or uneven trochees in Latin

$\begin{array}{llll}\text { a. HLL } & \text { type lāmīnă } & \begin{array}{l}\text { even trochees } \\ \text { ('lā)mīnă }\end{array} & \begin{array}{l}\text { uneven trochees } \\ \text { ('lāmī)nă }\end{array} \\ \text { b. LLH } & \text { type sŏlĭdus } & \text { ('sǒlī)dus } & \text { ('sǒlī)dus } \\ \text { c. HLH } & \text { type ārĭdus } & \text { ('ā)rĭdus } & \text { ('ārī)dus }\end{array}$

Jacobs (2019) argues for the need of a foot-based vowel deletion constraint based on vowel deletion in words such as balineum 'bath' and opitumus 'the best'. These words, that is words of four syllables with the first three syllables light, had initial stress in early Classical Latin, when all other word types did have penult or antepenult stress (cf. Lindsay 1894 and Jacobs 2003 for a formal OT account). When no reference is made to the foot for vowel deletion, output candidates ('bali) num or ('bal)num for underlying /balineum/ will be preferred over actual ('bal) neum. This is illustrated within parallel OT in (18) and (19). Jacobs (2019) deviates from the parallel and serial analyses discussed in section 1 by using the constraints Align W/R and Align W/L (cf. McCarthy and Prince (1993), Kager (1999) which require the word to be right- or left-aligned with a foot. In early Classical Latin ALIGN W/L was ranked above ALIGN W/R, whereas the opposite ranking holds for Classical Latin.

2. The uneven trochee has been motivated in, among others, Repetti (1998) and Revithiadou (2004), see also Hyde (2011), Mellander (2003) and Iversen, Patel and Ohgushi (2008) for more discussion. 
(18) *WEAK-V and vowel deletion in words like balineum

\begin{tabular}{|l|l|l|l|l|l|}
\hline ba.li.ne.um & ALIGN-W/L & $*$ WEAK-V & MAX-V & ALIGN-W/R & PARSE- $\sigma$ \\
\hline 1.('ba.li)ne.um & & $*$ ! $*$ & & $\sigma \sigma$ & $* *$ \\
\hline 2.ba ('li.ne)um & $\sigma !$ & $* *$ & & $\sigma$ & $* *$ \\
\hline 3.('bal)ne.um & & $* !$ & $*$ & $\sigma \sigma$ & $* *$ \\
\hline 4.('bal.ne)um & & $* !$ & $*$ & $\sigma$ & $*$ \\
\hline 5.('ba.li)num & & $* !$ & $*$ & $\sigma$ & $*$ \\
\hline 6. ('bal)num & & & $* *$ & $\sigma$ & $*$ \\
\hline
\end{tabular}

(19) *WEAK-V in FT and vowel deletion in words like balineum

\begin{tabular}{|l|l|l|l|l|l|}
\hline ba.li.ne.um & ALIGN-W/L & $*$ WEAK-V IN FT & MAX-V & ALIGN-W/R & PARSE- $\sigma$ \\
\hline 1.('ba.li)ne.um & & $* !$ & & $\sigma \sigma$ & $* *$ \\
\hline 2.ba ('li.ne)um & $\sigma !$ & $*$ & & $\sigma$ & $* *$ \\
\hline 3. ('bal)ne.um & & & $*$ & $\sigma \sigma$ & $* *$ \\
\hline 4.('bal.ne)um & & $* !$ & $*$ & $\sigma$ & $*$ \\
\hline 5.('ba.li)num & & $* !$ & $*$ & $\sigma$ & $*$ \\
\hline 6.(bal)num & & & $* * !$ & $\sigma$ & $*$ \\
\hline
\end{tabular}

As illustrated in (19) a foot-based vowel deletion constraint is required in a parallel analysis. If we switch from a Parallel to a Serial perspective, a number of remarks are in order. An output candidate ('bal.ne)um (18/19-4) is not a viable candidate in Harmonic Serialism when the derivation goes directly from ('ba.li)ne.um $\rightarrow$ ('bal.ne)um. This would imply two modifications at the same time: deletion of the vowel and footing or incorporation of the pre-final syllable into the main stress foot. If this is done stepwise, that is, vowel deletion after main stress, ('ba.li)ne.um $\rightarrow$ ('bal)ne.um, and, then, foot changing, ('bal)ne.um $\rightarrow$ ('bal.ne)um, it depends on how re-footing is conceived off. If it implies deleting the foot and then constructing a new one, it is excluded as a possible derivation, given that foot deletion does not constitute a harmonic improvement. If it is seen, not as foot deletion and foot construction, but as the incorporation of an unstressed syllable into an existing foot, it is allowed, depending on the ranking of relative ranking of RHHRM and PARSE- $\sigma$. If PARSE- $\sigma$ dominates RHHRM, a step from ('bal)ne.um to ('bal.ne)um is indeed an improvement in harmony. The more likely historical scenario seems to be that after vowel deletion at some point the word was indeed restructured or reanalysed in terms of footing in this way. In the evolution of 
balineum, there was no second round of vowel deletion given that vowel gliding (cf. Jacobs 2016) did turn the vowel in the pre-final syllable into a glide and changed the word into [balnju]. A second round of syncope did occur in a word like *deksiteros which in Early Classical Latin with initial stress was presumably parsed as ('deksi)teros and after syncope at some point as ('dekste)ros and, after a second round of syncope as ('deks)tros, ended up as dexter 'right' in Classical Latin (cf. Shen 2012).

Similar remarks hold for output candidate ('bal)num (18/19-6). Although possible from a parallel perspective, the single-modification-at-the-same-time limitation of the serial analysis excludes it from being a viable output candidate. However, even if output candidate (18/19-6) and (18/19-4) were omitted from evaluation, then, still, with the *WEAK-V constraint (thus without referring to the foot), output candidate (18-5), ('ba.li)num, would wrongly be selected in a serial analysis. We therefore need, both in a parallel and in a serial analysis, an uneven trochee and a vowel deletion constraint that makes reference to the foot. Further motivation for the necessity of foot-based constraints can be found in De Lacy (2002) who motivates foot-based constraints on the basis of Dutch vowel reduction. Before turning to the cross-level interaction in section 2.3 , we will first show why a serial analysis of vowel deletion has to be preferred over a parallel account.

\subsection{Why a serial analysis of vowel deletion should be preferred over a parallel analysis}

In Jacobs (2008) it is shown that syncope in cases such as sōlǐcŭlum [so:'li.ku.lum] $>$ sōlǐclum [so:('li)klum] 'sun' leads to surface prosodic opacity. In the syncopated form, main stress is on the light penultimate syllable, violating the constraint FT-BIN, requiring that feet should be binary, that is, either consisting of two syllables or be heavy (consisting of two moras). Normally, if the penultimate syllable is light, as in locuples 'rich' or Patroclus 'Proper name' main stress is on the antepenultimate syllable. In Parallel OT, this is problematic, given that one and the same ranking could never evaluate surface forms with an identical prosodic surface shape differently, as illustrated in (20) and (21).

(20) Parallel parsing of Patroclus.

\begin{tabular}{|l|l|l|l|l|l|l|}
\hline$/$ LLH/ & NON-FIN (FT) & FT-BIN & $\begin{array}{l}\text { ALIGN-R } \\
\text { MAIN- } \sigma\end{array}$ & WSP & PARSE- $\sigma$ & RHHRM \\
\hline L('LH) & $* !$ & & $\sigma$ & $*$ & $*$ & \\
\hline L('L)H & & $* !$ & $\sigma$ & & $* *$ & \\
\hline$\sigma(' \mathrm{LL}) \mathrm{H}$ & & & $\sigma \sigma$ & & $*$ & \\
\hline
\end{tabular}


(21) Problematic parallel parsing of so:'liklum. Stress is incorrectly predicted to shift.

\begin{tabular}{|c|c|c|c|c|c|c|}
\hline /HLH/ & Non-Fin (FT) & FT-BIN & $\begin{array}{l}\text { Align-R } \\
\text { MAIN- } \sigma\end{array}$ & WSP & Parse- $\sigma$ & RHHRM \\
\hline$\varpi(' \mathrm{HL}) \mathrm{H}$ & & & $\sigma \sigma$ & & $*$ & * \\
\hline : $\mathrm{H}(\mathrm{L}) \mathrm{H}$ & & $* !$ & $\sigma$ & & $* *$ & \\
\hline ('H)LH & & & $\sigma \sigma$ & & $* * !$ & \\
\hline $\mathrm{H}\left({ }^{\prime} \mathrm{LH}\right)$ & $* !$ & & $\sigma$ & * & $*$ & \\
\hline
\end{tabular}

Jacobs (2008) presents a serial analysis using OT with candidate chains (OTCC) (cf. McCarthy 2007). Parallel transparent competitors to opaque [so:'li.klum] such as sōlǐclum, ['so:li.klum], with a stress shift, but with transparent surface stress, or ['so:l.klum], with two vowels deleted, but also with transparent surface stress, constitute ill-formed candidate chains and are therefore no real competitors.

This is in a nutshell the analysis. A candidate chain <so:likulum, so:('li.ku) lum $>$ is fine, there is harmonic improvement, given that the high-ranked constraint HEADWORD, requiring a word to have stress is no longer violated. A chain <so:likulum, so:('li.ku)lum, so:('li)klum > is also fine. The further modification of so:('li.ku)lum into so:('li)klum is again an harmonic improvement, given that *WeAK-V dominates MAX-V. A chain <so:likulum, so:('li.ku)lum, so:('li)klum, ('so:li)klum > is, however, ill-formed as the change from so:('li)klum to ('so:li)klum contains two modifications at the same time: stress deletion and stress assignment. If the two changes are done separately, that is, so:('li)klum, so:liklum, ('so:li) klum, then the change from so:('li)klum to so:liklum, again, is not an harmonic improvement given the high-ranked HEADWORD constraint. Similar remarks hold for a transparent surface stress competitor ['so:l.klum]. The serial OT analysis thus has a clear advantage over a Parallel OT analysis: metrically conditioned vowel deletion can never lead to stress shift, not even when that would lead to surface prosodic transparency (cf. McCarthy 2008 for a similar argumentation). Let us next turn to the cross-level constraint interaction in Latin vowel deletion.

\subsection{Vowel deletion and cross-level interactions}

Let us now address the cross-level interaction in Latin vowel deletion. The crucial ranking parts required for the OT-CC analysis in Jacobs (2008) are illustrated in (22) and (23). In (22), we first give the two candidate chains for transparent vowel deletion in ('soli)dum $>$ ('sol)dum for which the relative ranking of *WEAK-V and MAX-V with respect to FT-BIN is irrelevant. 
(22) *WEAK-V and MAX-V may be ranked below FT-BIN for transparent solidum $>$ soldum

\begin{tabular}{|l|l|l|l|}
\hline so.li.dum & FT-BIN & $*$ WEAK-V & MAX-V \\
\hline 1. $<$ solidum, ('so.li)dum $>$ & & $* !$ & \\
\hline 2. $<$ <solidum, ('so.li)dum, ('sol)dum> & & & $*$ \\
\hline
\end{tabular}

However, the ranking in (22) cannot be the ranking for opaque vowel deletion in soliculum. Here, it is crucial that both *WEAK-V and MAX-V are ranked above FT-BIN, as illustrated in (23).

(23) Both *WEAK-V and MAX-V must be ranked above FT-BIN for opaque so'liclum

\begin{tabular}{|l|l|l|l|}
\hline so.li.ku.lum & $*$ WEAK-V & MAX-V & FT-BIN \\
\hline 1. $<$ so:likulum, so: ('li.ku)lum> & $* !$ & & \\
\hline 2. $<$ so:likulum, so:('li.ku)lum, so:('li)klum> & & $*$ & $*$ \\
\hline
\end{tabular}

In (23) the two well-formed candidate chains for opaque soliclum are evaluated. Chain 23-1, <so:likulum, so:'li.ku)lum $>$ is a well-formed chain. The further modification of so:('li.ku)lum into so:('li)klum, as in chain 23-2, constitutes also an harmonic improvement, given that *WEAK-V dominates MAX-V, but crucially, for that analysis to go through, the constraints *WEAK-V and MAX-V both have to dominate the constraint FT-BIN, which will have no consequences for transparent vowel deletion in (22), given that chain 22-2 does not have a violation of FT-BIN.

If we translate this analysis into Harmonic Serialism, then, the full constraint ranking in which HEADWORD dominates *WEAK-V > MAX-V, which in their turn, dominate FT-BIN, raises the question why words like solidum and soliculum are footed as ('soli)dum and so:('licu)lum to begin with, if the *WEAK-V > MAX-V ranking judges them to be suboptimal? Why do the wrong footing first and then improve on it by vowel deletion?

In order to answer this question, it is first of all important to mention that it is not the case that ('LL) or ('HL) feet did never surface in Latin. Vowel deletion, which was an optional process that started in Pre-classical Latin and was active throughout the history of the language as witnessed by the optimus, balneum (Preclassical) and periclum and maniplum (Classical) cases discussed above, started out by targeting mainly high vowels and by being sensitive to phonotactic constraints. Vowel deletion in words like vetulus 'old' only occurred in Late Latin (cf. the Appendix Probi "vetulus non veclus"). This means that, instead of the general vowel deletion constraint *WEAK-VOWEL IN FT, we need a more specific constraint, *WEAK-HIGH IN FT (targeting high vowels), and we also need to check vowel deletion for phonotactic compatibility. We can now assume that the suboptimal LL foot created in the derivation of so:likulum $\rightarrow$ so:('li.ku)lum $\rightarrow$ so:('li)klum results directly from the footing constraints or in the case of the suboptimal HL foot in 
the derivation of a:ridus $\rightarrow$ ('a:ri)dus $\rightarrow$ ('a:r)dus is enforced by PARSE- $\sigma$, much in the same way as an uneven trochee would be required at an intermediate step in a serial analysis of trochaic shortening in Fijian or of tri-syllabic laxing in English as mentioned above. Therefore, what happens from a serial perspective is that a foot is first constructed and only after that, at a next step, inspected for possible vowel deletion, but both crucially cannot take place at the same time. This is visualized, after syllabification at step 1 , in (24) for words like solidus and vetulus.

(24) Step 2: so.li.dus and ve.tu.lus going to ('so.li.)dus and ('ve.tu)lus LLH becomes ('LL)H

\begin{tabular}{|c|c|c|c|c|c|c|c|}
\hline /LLH/ & $\begin{array}{l}\text { HEAD } \\
\text { WORD }\end{array}$ & $\begin{array}{l}\text { *WEAK- } \\
\text { HIGH IN FT }\end{array}$ & MAX-V & $\begin{array}{l}\text { NoN-FIN } \\
(\mathrm{FT})\end{array}$ & FT-BIN & $\begin{array}{l}\text { AliGN-R } \\
\text { MAIN- } \sigma\end{array}$ & PARSE- $\sigma$ \\
\hline 1. ('LL)H & & & & & & $\sigma \sigma$ & $*$ \\
\hline 2. LLH & *! & & & & & & $* * *$ \\
\hline 3. $\mathrm{L}\left({ }^{\prime} \mathrm{L}\right) \mathrm{H}$ & & & & & $* !$ & $\sigma$ & $* *$ \\
\hline 4. $\mathrm{L}\left({ }^{\prime} \mathrm{LH}\right)$ & & & & *! & & $\sigma$ & $*$ \\
\hline
\end{tabular}

The dotted line between the second and third constraint expresses the optionality of vowel deletion and indicates that the relative ranking between them is not fixed. The important thing to observe is that output candidate (24-3) is ruled out as it violates FT-BIN.

The foot ('LL)H is then inspected for possible improvement at step 3 in the derivation. In the case of a word like ('so.li.)dus vowel deletion constitutes a harmonic improvement as illustrated in (25), where we have left out FT-BIN and where the two optimal output forms represent the optional status of vowel deletion.

(25) Step 3: ('so.li.)dus optionally going to ('sol)dus. ('LL)H may become ('H)H

\begin{tabular}{|l|l|l|l|l|l|l|}
\hline$/($ 'so.li.)dus/ & $\begin{array}{l}\text { HEAD } \\
\text { WORD }\end{array}$ & $\begin{array}{l}* \text { WEAK- } \\
\text { HIGH IN FT }\end{array}$ & MAX-V & $\begin{array}{l}\text { Non-FIN } \\
(\mathrm{FT})\end{array}$ & $\begin{array}{l}\text { ALIGN-R } \\
\text { MAIN- } \sigma\end{array}$ & PARSE- $\sigma$ \\
\hline 2. solidus & $*$ 1.('sol)dus & & $*$ & & $\sigma$ & $*$ \\
\hline 3.('soli)dus & & $*$ & & & & $* * *$ \\
\hline 4. $*$ L('LH) & & & & & $\sigma \sigma$ & $*$ \\
\hline
\end{tabular}

Please observe that candidate (24-4), which we have repeated as (25-4), is no longer an option at step 3, given that it would require two modifications at one step: the deletion of the foot ('soli) and the assignment of the foot ('lidus). Please observe also that optional vowel deletion does not take place in Classical Latin for words 
like ('ve.tu)lus at step 3, due to higher-ranked phonotactic constraints which, for reasons of space, have been left out in (24) and (25).

Given that in this serial analysis the vowel deletion constraint is only evaluated after a foot has been assigned, no violations have been provided for the two constraints *WEAK-HIGH IN FT and MAX-V in (24). To make this more precise we repeat in (26) tableau (24), but with the violations for these two constraints, if one were able to evaluate them at step 2 and an output form (26-5) in which the vowel has been deleted.

(26) Step 2: so.li.dus going directly to ('sol)dus?

\begin{tabular}{|l|l|l|l|l|l|l|l|}
\hline$/$ LLH/ & $\begin{array}{l}\text { HEAD } \\
\text { WORD }\end{array}$ & $\begin{array}{l}* \text { WEAK- } \\
\text { HIGH IN FT }\end{array}$ & MAX-V & $\begin{array}{l}\text { NON-FIN } \\
(\mathrm{FT})\end{array}$ & $\begin{array}{l}\text { FT- } \\
\text { BIN }\end{array}$ & $\begin{array}{l}\text { ALIGN-R } \\
\text { MAIN- }\end{array}$ & PARSE- \\
\hline 1.('soli)dus & & $*$ & & & & $\sigma \sigma$ & $*$ \\
\hline 2. solidus & $* !$ & & & & & & $* * *$ \\
\hline 3. so('li)dus & & $*$ & & & $* !$ & $\sigma$ & $* *$ \\
\hline 4. so('lidus) & & $*$ & & $* !$ & & $\sigma$ & $*$ \\
\hline$\leftarrow 5$. ('sol)dus & & & $*$ & & & $\sigma$ & $*$ \\
\hline
\end{tabular}

If the derivation at step 2 would work like this, this would imply that at step 2 not only two modifications are required: deleting a vowel and assigning a foot, but also that footing would need to do something that never occurs in stress systems, that is, footing would need to inspect segmental features like [+high] and phonotactic well-formedness constraints in order to decide whether to assign a monosyllabic foot (as in (26-5) or not as in ('ve.tu)lus. The derivation of opaque of so:likulum $\rightarrow$ so:('li. $\mathrm{ku})$ lum $\rightarrow$ so:('li)klum proceeds essentially along the same lines. The intermediate foot ('li.ku) is enforced by the regular footing constraints and the surface violation of FT-BIN in so:('li)klum is enforced by the higher-ranked vowel deletion constraint *WEAK-HIGH IN FT. This illustrated for step 2 and 3 in the derivation in (27) and (28).

(27) Step 2: so:li.ku.lum going to so:('li.ku)lum.

\begin{tabular}{|l|l|l|l|l|l|l|l|}
\hline /so:('li.ku)lum / & $\begin{array}{l}\text { HEAD } \\
\text { WORD }\end{array}$ & $\begin{array}{l}\text { *WEAK- } \\
\text { HIGH IN FT }\end{array}$ & MAX-V & $\begin{array}{l}\text { NON-FIN } \\
\text { (FT) }\end{array}$ & $\begin{array}{l}\text { FT- } \\
\text { BIN }\end{array}$ & $\begin{array}{l}\text { ALIGN-R } \\
\text { MAIN- } \sigma\end{array}$ & PARSE- $\sigma$ \\
\hline 1 ('so:li)ku.lum & & & & & & $\sigma \sigma \sigma !$ & $* *$ \\
\hline 2('so:)li.ku.lum & & & & & & $\sigma \sigma \sigma !$ & $* * *$ \\
\hline 3 so:('li)ku.lum & & & & & $* !$ & $\sigma \sigma$ & $* * *$ \\
\hline 4 so:.li('ku)lum & & & & & $* !$ & $\sigma$ & $* * *$ \\
\hline 5 so:li.ku.lum & $* !$ & & & & & & $* * *$ \\
\hline$\sigma 6$ so:('li.ku)lum & & & & & & $\sigma \sigma$ & $* *$ \\
\hline
\end{tabular}


(28) Step 3: so:('li.ku)lum optionally realised as so:('li)klum.

\begin{tabular}{|c|c|c|c|c|c|c|c|}
\hline /so:('li.ku)lum / & $\begin{array}{l}\text { HEAD } \\
\text { WORD }\end{array}$ & $\begin{array}{l}* \text { WEAK- } \\
\text { HIGH IN FT }\end{array}$ & MAX-V & $\begin{array}{l}\text { Non-FIN } \\
(\mathrm{FT})\end{array}$ & $\begin{array}{l}\text { FT- } \\
\text { BIN }\end{array}$ & $\begin{array}{l}\text { ALIGN-R } \\
\text { MAIN- } \sigma\end{array}$ & PARSE- $\sigma$ \\
\hline 1 so:('li)klum & & & $*$ & & $*$ & $\sigma$ & $* *$ \\
\hline 2 so:li.ku.lum & *! & & & & & & \\
\hline -3 so:('li.ku)lum & & * & & & & $\sigma \sigma$ & $* * *$ \\
\hline
\end{tabular}

Let us next turn to a second case in the phonology of Latin where a cross-level constraint interaction can be observed: vowel gliding.

\section{Vowel gliding and cross-level interactions}

The hiatus resolution by the vowel gliding of the non-low vowels (i, e, u, o) before another vowel in Late Latin, generally dated in the first century AD, is illustrated in (29) where the French reflexes have also been indicated (cf. Pope 1934: 102; Lindsay 1984: 142; Bourciez 1974: 28; Fouché 1958: 28, among others).

(29) Vowel gliding of i, e, u, o in hiatus

$\begin{array}{llllll} & \text { Classical Latin } & \text { Late Latin } & \text { Old French } & \text { French } & \\ \text { filium } & \text { ['filium] } & \text { ['filju] } & \text { fil } & \text { fils } & \text { 'son' } \\ \text { vineam } & \text { ['wineam] } & \text { ['winja] } & \text { vigne } & \text { vigne } & \text { 'vine' } \\ \text { vidua } & \text { ['widuam] } & \text { ['wedwa] } & \text { veve, vedve } & \text { veuve } & \text { 'widow' } \\ \text { coacticare } & \text { [koakti'kare] } & \text { [kwakti'kare] } & \text { cachier } & \text { cacher } & \text { 'to hide' }\end{array}$

The relation between vowel gliding in (29) and stress displays a paradox that has never been properly understood. All traditional descriptions of the facts agree that in order for vowel gliding to take place the non-low vowel in hiatus had to be

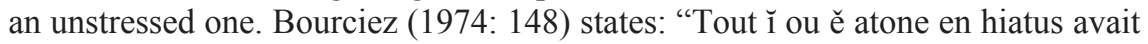
pris la valeur de y..." [every unstressed i or e in hiatus has taken the value of $j$, ]

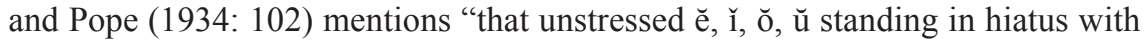
a following vowel gradually lost syllabic value and consonantalised". If vowel gliding was indeed restricted to unstressed vowels, it becomes immediately clear why it did not take place in disyllabic words, as illustrated by the forms in (30).

(30) No vowel gliding in disyllabic words

\begin{tabular}{|c|c|c|c|c|c|}
\hline deum & $\begin{array}{l}\text { Classical Latin } \\
\text { ['deum] }\end{array}$ & $\begin{array}{l}\text { Late Latin } \\
{[\mathrm{deu}]}\end{array}$ & $\begin{array}{l}\text { Old French } \\
\text { deo, de, dieu, }\end{array}$ & $\begin{array}{l}\text { French } \\
\text { dieu }\end{array}$ & $\begin{array}{l}\text { Gloss } \\
\text { 'God' }\end{array}$ \\
\hline & ['gruem] & [grue] & & grue & 'crane' \\
\hline & ['ego] & [eo] & eo, io, jeu, & je & 'I' \\
\hline & ['diem] & [die] & & -di- & -day- \\
\hline & ['mea] & [mea] & meie, moie & mienne & 'mine' \\
\hline & ['piam] & [pia] & pie & pieuse & 'devout' \\
\hline & ['wiam] & [wea] & veie & voie & ‘way’ \\
\hline
\end{tabular}


The forms in (31) further show that the absence of vowel gliding in (30) is unrelated to the vowel in hiatus being in initial position. That is, vowel gliding did take place word-initially.

(31) Vowel gliding word-initially

$\begin{array}{llllll} & \text { Classical Latin } & \text { Late Latin } & \text { Old French } & \text { French } & \text { Gloss } \\ \text { diurnum } & {[\text { di.'ur.num }]} & {[\text { dj/dzornu }]} & \text { jorn, jor } & \text { jour } & \text { 'day' } \\ \text { georgium } & \text { [ge.'or.gi.um }] & {[\mathrm{gj} / \text { dzorgj/dzu }]} & \text { Georges } & \text { Georges id. } \\ \text { quietum } & {[\text { kwi.'e.tum }]} & {[\text { kwjeta }]} & \text { coi } & \text { tranquille 'calm' } \\ \text { duodecim } & {[\text { du.'o.d.ekim }]} & {[\text { dwodetsi }]} & \text { dose } & \text { douze 'twelve' }\end{array}$

The forms in (32), finally, show that, paradoxically, stressed vowels were subject to vowel gliding.

(32) Vowel gliding of stressed vowels

$\begin{array}{llllll} & \text { Classical Latin } & \text { Late Latin } & \text { Old French } & \text { French } & \text { Gloss } \\ \text { filiolum } & \text { [fi'li.o.lum] } & \text { [fil'jolu] } & \text { filuel } & \text { filleul } & \text { 'godson' } \\ \text { tiliam *tiliolu } & \text { [ti'li.o.lum] } & \text { [til'jolu] } & \text { tilleul } & \text { tilleul } & \text { 'lime' } \\ \text { gladiolum } & \text { [gla'di.o.lum] } & \text { [gla'djolu] } & \text { glaïeul } & \text { glaïeul } & \text { 'gladiolus' } \\ \text { mulierem } & \text { [mu'li.e.rem }] & \text { [mu'ljere] } & \text { moillier } & --- & \text { 'wife' }\end{array}$

Traditional analyses have never been able to account for the vowel gliding of stressed vowels. Jacobs (2016) shows that the paradoxical relationship between stress and vowel gliding receives a straightforward explanation when it is considered from a serial instead of a parallel OT perspective. It allows the prosody of the language to determine whether or not vowel gliding takes place, but, importantly, the vowel gliding itself can be formalized without any reference to stress at all.

The constraints in (33) are needed to describe the vowel gliding.

(33) Constraints for hiatus resolution

No Hiatus : Avoid two adjacent hetero-syllabic vowels

MAX- $\mu$ : $\quad$ Do not delete a vowel's mora

The hierarchy in (34a) is proposed for Classical Latin and vowel gliding that started in early Late Latin is accounted for by assuming that the hierarchy changed into the one in (34b) in Late Latin. This means that the only change in the grammar is related to vowel gliding, but that the prosodic grammar, a part of the hierarchy in (34) remained unchanged.

(34a) Classical Latin hierarchy for stress and hiatus

Non-Fin $($ FT) $>$ MAX $-\mu>$ No Hiatus $>$ FT-BIn $>$ Align-R Main- $\sigma$ $>$ PARSE- $\sigma$

(34b) Late Latin hierarchy for stress and hiatus

Non-Fin $($ FT) $)>$ No Hiatus $>$ MAX $-\mu>$ FT-BIn $>$ ALIGn-R MaIn- $\sigma>>$ PARSE- $\sigma$ 
In Classical Latin, the evaluation for a word like diurnum, converges stresswise on the output form [di.('ur)num] in the second evaluation round, as illustrated in (35) and (36).

(35) Second step in Classical Latin: /di.ur.num/ becomes [di.('ur)num]

\begin{tabular}{|l|l|l|l|l|l|l|}
\hline / di.ur.num/ & $\begin{array}{l}\text { Non-FIN } \\
\text { (FT) }\end{array}$ & MAX- $\mu$ & $\begin{array}{l}\text { No } \\
\text { HIATUS }\end{array}$ & FT-BIN & $\begin{array}{l}\text { Align-R } \\
\text { MAIN- } \sigma\end{array}$ & PARSE- $\sigma$ \\
\hline 1. (,di).('ur) num & & & $*$ & $* !$ & $\sigma$ & $*$ \\
\hline 2. ${ }^{\circ}$ di.('ur) num & & & $*$ & & $\sigma$ & $* *$ \\
\hline 3. di.('ur)(,num) & $* !$ & & $*$ & & $\sigma$ & $*$ \\
\hline
\end{tabular}

Tableau (36) shows that vowel gliding does not lead to further harmonic improvement in the next round of evaluation, but that grammar (34a) converges on [di.('ur)num].

(36) Third step for diurnum in Classical Latin: convergence, no vowel gliding

\begin{tabular}{|l|l|l|l|l|l|l|}
\hline / di.('ur)num/ & $\begin{array}{l}\text { Non-FIn } \\
\text { (FT) }\end{array}$ & MAX- $\mu$ & $\begin{array}{l}\text { No } \\
\text { Hiatus }\end{array}$ & FT-BIn & $\begin{array}{l}\text { Align-R } \\
\text { MAIN- } \sigma\end{array}$ & PARSE- $\sigma$ \\
\hline 1.(di).('ur) num & & & $*$ & $* !$ & $\sigma$ & $*$ \\
\hline 2. di.('ur)num & & & $*$ & & $\sigma$ & $* *$ \\
\hline 3.('djur)num & & $* !$ & & & $\sigma$ & $*$ \\
\hline 4.di.('ur)(,num) & $* !$ & & $*$ & & & $*$ \\
\hline
\end{tabular}

Output candidate (36-3) with vowel gliding is not harmonically improving, but worse when compared to winning output candidate (36-2) [di.('ur)num]. In Late Latin, however, given the changed ranking of the two relevant constraints, vowel gliding does lead to further harmonic improvement, as shown in tableau (37).

(37) Third step for diurnum in Late Latin (34b): vowel gliding

\begin{tabular}{|l|l|l|l|l|l|l|}
\hline / di.('ur)num/ & $\begin{array}{l}\text { Non-FIn } \\
\text { (FT) }\end{array}$ & $\begin{array}{l}\text { No } \\
\text { Hiatus }\end{array}$ & MAX- $\mu$ & FT-BIN & $\begin{array}{l}\text { Align-R } \\
\text { MAIN- } \sigma\end{array}$ & PARSE- $\sigma$ \\
\hline 1.(di).('ur) num & & $* !$ & & $*$ & $\sigma$ & $*$ \\
\hline 2. di.('ur)num & & $* !$ & & & $\sigma$ & $* *$ \\
\hline 3. ('djur)num & & & $*$ & & $\sigma$ & $*$ \\
\hline 4.di.('ur)(,num) & $* !$ & $*$ & & & & $*$ \\
\hline
\end{tabular}


Tableau (37) shows that, in Late Latin, the output candidate (37-3) with vowel gliding is harmonically improving when compared to output candidate (37-2) [di.('ur)num] as it succeeds in avoiding a violation of the constraint No HIATUS.

Let us now turn to the blocking of vowel gliding in disyllabic words (cf. (30) above), which straightforwardly results from the grammar in (34b). In (38), the fate of disyllabic viam during the second round of evaluation in Late Latin is illustrated.

(38) Third step for viam in Late Latin: convergence, no vowel gliding

\begin{tabular}{|l|l|l|l|l|l|l|}
\hline$/$ ('vi)am/ & $\begin{array}{l}\text { Non-FIn } \\
(\mathrm{FT})\end{array}$ & $\begin{array}{l}\text { No } \\
\text { HiATUS }\end{array}$ & MAX- $\mu$ & FT-BIn & $\begin{array}{l}\text { ALIGN-R } \\
\text { MAIN- } \sigma\end{array}$ & PARSE- $\sigma$ \\
\hline 1 ('vi.am) & $* !$ & $*$ & & & $\sigma$ & \\
\hline 2 ('vjam) & $* !$ & & $*$ & & & \\
\hline $3 \leftarrow$ ('vi)am & & $*$ & & $*$ & $\sigma$ & $*$ \\
\hline
\end{tabular}

The ranking of the constraints NON-FIN and FT-BIN above the vowel gliding constraints straightforwardly accounts for the absence of vowel gliding in disyllabic words. Let us next look more closely at the effect of vowel gliding in the problematic forms in (32) above. The important thing to observe is that the shift of stress from the antepenultimate to the penultimate syllable does not imply literally a change in foot structure. That is, the foot is shortened by one syllable, but stress remains to be expressed by the same foot. In (39) we illustrate the third step in the derivation of [mu.('li.e)rem] in Late Latin.

(39) Third step for mulierem in Late Latin: vowel gliding

\begin{tabular}{|c|c|c|c|c|c|c|}
\hline /mu.('li.e)rem/ & $\begin{array}{l}\text { Non-FIN } \\
(\mathrm{FT})\end{array}$ & $\begin{array}{l}\text { No } \\
\text { HiATUS }\end{array}$ & MAX- $\mu$ & FT-BIN & $\begin{array}{l}\text { ALIGN-R } \\
\text { MAIN- } \sigma\end{array}$ & PARSE- $\sigma$ \\
\hline 1mu.('li.e)rem & & $* !$ & & & $\sigma \sigma$ & $* *$ \\
\hline 2mu.('lje.rem) & $* !$ & & $*$ & & $\sigma$ & $*$ \\
\hline $3 \oplus$ mul.('je)rem & & & $*$ & $*$ & $\sigma$ & $*$ \\
\hline $4^{*} ?($ 'mul.je)rem & & & $*$ & & $\sigma \sigma$ & $*$ \\
\hline $5 * ?(' \mathrm{mul}) \mathrm{je} . \mathrm{rem}$ & & & $*$ & & $\sigma \sigma$ & $* *$ \\
\hline
\end{tabular}

As shown in (39-3), harmonic improvement by vowel gliding is possible in at the third step in the derivation for mulierem. A parallel account would predict, dependent on the relative ranking of PARSE- $\sigma$ and RHHRM, either candidate (394) or (39-5) to be incorrectly selected as the optimal output. Both these output candidates are ruled out as possible output forms in Harmonic Serialism, given that 
they imply two modifications at the same time, instead of the allowed single one single modification. In order to get from input /mu('li.e)rem/ in (39) to unwanted [('mul.je)rem] in (39-4) or to [('mul)je.rem] in (39-5) two modifications are required at step 3 in the derivation: removal of stress from the antepenultimate syllable and assignment of stress to the first syllable, of which the first modification is not allowed. If stress was first undone, in one step, and then reassigned later, in a second step, the first step would not be harmonically improving, given the highranked HEAD-WORD constraint, which would be violated by an intermediate form without stress or without a foot. This is a clear advantage of Serial OT over Parallel OT: once stress has been assigned, it can no longer be undone, as that would require two modifications at the same time.

Let us summarize thus far. The link between glide resolution and stress is an indirect one. Vowel gliding is not directly metrically conditioned (in the sense that only unstressed vowels are subject to it), in fact, it is not metrically conditioned at all, but applies to stressed and to unstressed vowels alike. It is the prosodic system of the language that determines whether or not vowel gliding applies. More specifically, in words like deum and viam in (30), vowel gliding did not take place, because going from ('vi.)am to ('vjam) is not a harmonic improvement, contrary to the other cases where gilding did take place, as illustrated above.

However, here too, we are facing a problematic cross-level interaction. The basic issue is this: the tableaux (35) to (39) start out by stressing or footing the underlying form. In order to do footing the forms need to be syllabified, given that syllable structure is required for stressing to take place, but then the following question arises: why would, for instance (38), to begin with be syllabified with a hiatus if the constraint against it is high ranked? Why first syllabify the input string as involving a hiatus and only then harmonically improve it? Contrary to stress, or feet, as discussed above, syllable structure needs to escape the requirement that once assigned it can no longer be undone. Resyllabification does occur without problems, as in (39-3) where [1] is onset before, but coda after vowel gliding, contrary to the shifting of stress to the initial syllable in (39-4). McCarthy (2007: 76) assumes that "syllabic parsing is not subject to faithfulness and therefore that syllables may be freely assigned and reassigned in chains. Metrical parsing [...] is subject to faithfulness" and this is what would be needed for our analysis to go through as well. We would like to exclude (39-4) on the grounds that metrical parsing is subject to the harmonic improvement requirements in Harmonic Serialism, while at the same time maintaining a syllabified input with the possibility of freely changing it elsewhere, as in (35) to (39). So we need to assume that syllable structure can be freely assigned and reassigned at each step in the derivation. We assume that when gliding began syllable structure is present in the input forms. There is one piece of evidence that this is really needed. If we compare Classical Latin iam [jam] 'already' or ius [jus] 'law' with viam [wi.am] and piam [pi.am] it is clear that the distribution of high vowels and glides, which was predictable in Classical Latin (Steriade 1988), ceased to be so a at a later point in time when vowel gliding started. If the explanation for the non-gliding in the latter two words is related to high-ranked NON-FIN (FT), it must be the case that the first two words, albeit with 
predictable syllabification in Classical Latin, were stored with syllable structure in Late Latin.

\section{Summary}

In this paper, after having critically reviewed the analysis of vowel shortening proposed by McCarthy, Pater \& Pruitt (2016), we have addressed two cases of crosslevel interactions in Latin, one in vowel deletion and another one in vowel gliding. We have argued that a serial analysis has to be preferred over a parallel analysis, given that it straightforwardly not only accounts for prosodic opacity resulting from vowel deletion and from vowel gliding, but also for the fact that both stressed and unstressed vowels could be subject to vowel gliding.

\section{References}

Allen, W. Sidney. 1973. Accent and Rhythm. Cambridge: Cambridge University Press. Bourciez, Edouard \& Jean Bourciez, 1967 [1974]. Phonétique française. Paris: Klincksieck.

Drexler, Hans. Die Iambenkürzung: Kürzung der zweiten Silbe eines iambischen Wortes, eines iambischen Wortanfangs. Hildesheim: Olms.

Fouché, Pierre, 1958. Phonétique historique du français. Paris: Klincksieck.

Hayes, Bruce. 1995. Metrical Stress Theory. Principles and Case Studies. Chicago: The University of Chicago Press.

Hyde, Brett. 2011. The Iambic-Trochaic Law. In Marc van Oostendorp, Colin Ewen, Elizabeth Hume \& Keren Rice (eds.). The Blackwell Companion to Phonology. Volume 2 Suprasegmental and Prosodic Phonology, 1052-1077.

Iversen, John, Aniruddh Patel \& Kengo Ohgushi. 2008. Perception of rhythmic grouping depends on auditory experience. The Journal of the Acoustical Society of America 124: 2263-2271.

Jacobs, Haike. 1999. Constraining constraints: NonFInALITY and the Typology of Footextrametricality. In Renée van Bezooijen \& René Kager (eds.) Linguistics in the Netherlands 1999, 111-129. Amsterdam: John Benjamins.

Jacobs, Haike. 2003. The Emergence of Quantity-Sensitivity in Latin: Secondary Stress, Iambic Shortening and theoretical implications for 'mixed' stress systems. In E. Holt (eds.). Optimality Theory and Language Change, 229-247. Dordrecht: Kluwer.

Jacobs, Haike. 2004. Rhythmic Vowel Deletion in OT: Syncope in Latin. Probus 16: 63-90.

Jacobs, Haike. 2008. Sympathy, comparative markedness, OT-CC and Latin syncope. Probus 20: 235-255.

Jacobs, Haike. 2016. L'interaction entre le système d'accentuation et la consonification des voyelles en hiatus dans la phonologie historique du français. Diachroniques 5: 79-103.

De Lacy, Paul. 2002. The Formal Expression of Markedness. Ph.D. dissertation, University of Massachusetts Amherst.

Lindsay, Wallace. 1894 [1963]. The Latin language. New York: Hafner. $2^{\text {nd }}$ edition.

McCarthy, John. 2003. OT constraints are categorical. Phonology 20: 75-138. 
McCarthy, John. 2007. Hidden Generalizations. Phonological Opacity in Optimality Theory. London: Equinox.

McCarthy, John. 2008. The serial interaction of stress and syncope. Natural Language and Linguistic Theory 26: 499-546.

McCarthy, John. 2010. Harmonic Serialism Supplement to Doing Optimality Theory. $<$ http://works.bepress.com/john_j_mccarthy/108>.

McCarthy, John, Joe Pater \& Kathryn Pruitt. 2016. Cross-level interactions in Harmonic Serialism. <http://works.bepress.com/john_j_mccarthy/113>.

Mellander, Evan. 2003. (HL)-creating processes in a theory of foot structure. The Linguistic Review 29: 243-280.

Mester, Ralph Armin. 1994. The Quantitative Trochee in Latin. Natural Language and Linguistic Theory 12, 1-61.

Pope, Mildred, 1934. From Latin to Modern French. Manchester: Manchester University Press.

Prince, Alan \& Paul Smolensky. 1993 [2004]. Optimality Theory. Constraint Interaction in Generative Grammar. Oxford: Blackwell.

Repetti, Lori. 1998. Uneven Trochees in Latin: Evidence from Romance Dialects. University of Venice Working Papers in Linguistics 8: 95-119.

Revithiadou, Anthi. 2004. The Iambic/Trochaic Law revisited. In Boban Arsenijevic, Noureddine Elouazizi, Martin Salzmann \& Mark de Vos (eds.). Leiden Papers in Linguistics 1.1: 37-62.

Shen, Ranjan. 2012. Reconstructing phonological change: duration and syllable structure in Latin and vowel reduction. Phonology 29: 465-504.

Steriade, Donca. 1984. Glides and Vowels in Romanian. Proceedings of the Tenth Annual Meeting of the Berkeley Linguistics Society, 47-64. 